\title{
MicroRNAs Responsible for Inflammation in Obesity
}

\author{
Caroline Brettfeld ${ }^{\mathrm{a}}$, Ales Maver ${ }^{\mathrm{b}}$, Eva Aumuller ${ }^{\mathrm{a}}$, Borut Peterlin ${ }^{\mathrm{b}}$, \\ Alexander G. Haslberger ${ }^{\mathrm{a}, \mathrm{c}}$
}

\begin{abstract}
Background: In recent years, more and more evidence has accumulated to elucidate the modulating roles of microRNA in immune and inflammatory system. We conducted a novel positional omics integration study to identify microRNAs that could shed further light on the possible links between microRNAs, adipose tissue immunity/inflammation and obesity.
\end{abstract}

Methods: In contrast to previous methodologies employed for integration of heterogeneous OMIC data, we based the integration on genomic positions of alterations in human disease and employed an additional weighing step. A data search for various types of studies on obesity (genome-wide association, meta-analysis, transcriptomic, proteomic studies and epigenetic studies) was conducted to establish the initial data set.

Results and discussion: The analysis identified 19 high scoring microRNAs (miR-146, miR-378, miR-143, miR-145, miR-194, miR1273, miR-190, miR-561, miR-151, miR-215, miR-196, miR-328, miR-208, miR-3155A, miR-933, miR-4685, miR-640, miR-4659, and miR-877). Five (miR-146, miR-378, miR-143, miR-145, and miR-194), which may be directly linked to adipose tissue inflammation or obesity-related diseases, eight other microRNAs (miR-1273, miR-190, miR-561, miR-151, miR-215, miR-196, miR-328, and miR-208) have been identified to play a role in cancer and myocardial infarction, where obesity is a defined risk factor.

Conclusion: In this study, we applied a new method of positional integrational analysis of different OMIC-layers and utilized an additional validation step through weighing. Our study yields a number of plausible microRNAs that provide an interesting basis for further research to elucidate underlying mechanisms of obesity. Our detection of common microRNAs which are also related with an increased risk for inflammations, cardiovascular problems and type 2 diabetes, irrespectively of gender and age may provide a path for understanding the inherited or acquired impact of microRNAs on human health

Manuscript submitted January 13, 2017, accepted January 23, 2017

aDepartment for Nutrition Sciences, University of Vienna, Austria bepartment of Human Genetics, University of Ljubljana, Slovenia ${ }^{\mathrm{c} C}$ Corresponding Author: Alexander G. Haslberger, Department for Nutrition Sciences, University of Vienna, Austria.

Email: alexander.haslberger@univie.ac.at

doi: https://doi.org/10.14740/jem399w and wellbeing.

Keywords: MicroRNA; Obesity; OMIC-data integration; Inflammation

\section{Introduction}

Obesity is a multifactorial condition that results from the interactions among genetic, dietary, environmental, and lifestyle factors [1]. In recent years, it has become an epidemic primarily due to a higher intake in high-caloric food and a decline in physical exercise [2]. The World Health Organization (WHO) has estimated that worldwide approximately 1.6 billion adults are overweight (body mass index $(\mathrm{BMI})>25$ ) and at least 400 million are obese (BMI > 30) [3]. Obesity is linked to an elevated morbidity due to cardiovascular diseases, to the development of insulin resistance and type 2 diabetes, and to certain types of cancer [4].

Obesity is typically defined by an extreme expansion of white adipose tissue, which has been believed to be the central location for the start of obesity-associated inflammation. Although adipose tissue's principal function is energy storage, it also serves as an active secretory organ. Collectively named "adipokines" describe a number of bioactive peptides or proteins that are generated and secreted by fat and/or non-fat cells of white adipose tissue. They act in an autocrine/paracrine manner to manage local adipose tissue function and also influence, in an endocrine manner, the functions of distant tissues such as liver, cardiovascular systems, skeletal muscle and central nervous systems $[5,6]$.

In obesity, adipocyte hypertrophy (increased size), hyperplasia (increased number), immune cell infiltration, endothelial cell overactivation, and extracellular matrix overproduction remodel white adipose tissue dynamically [7-10]. This remodeling may prompt hypoxic and metabolic stress, resulting in activation of multiple inflammatory signaling pathways, ultimately leading to dysregulation of numerous adipokines including proinflammatory cytokines, growth factors, chemokines, acute-phase proteins, and complement-like factors. Basically, all known adipokines are dysregulated in obesity. Such a disturbed homeostasis is an essential feature of adipose tissue low-grade inflammation [5].

In recent years, more and more evidence has accumulated to elucidate the modulating roles of microRNA in immune and inflammatory system $[11,12]$. 
Table 1. List of GWAS and Meta-Analysis for Initial Data Set

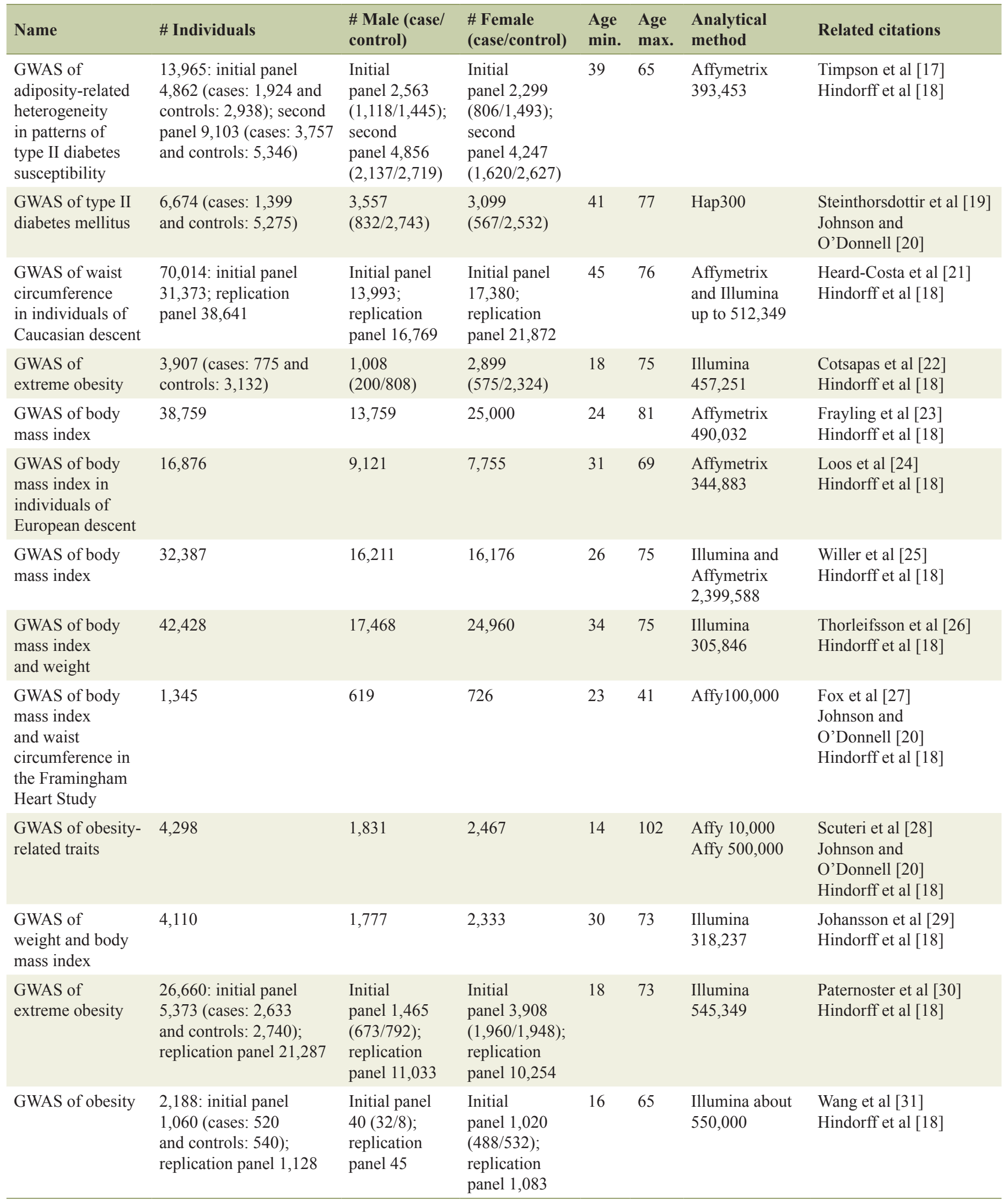


Table 1. List of GWAS and Meta-Analysis for Initial Data Set - (continued)

\begin{tabular}{|c|c|c|c|c|c|c|c|}
\hline Name & \# Individuals & $\begin{array}{l}\text { \# Male (case/ } \\
\text { control) }\end{array}$ & $\begin{array}{l}\text { \# Female } \\
\text { (case/control) }\end{array}$ & $\begin{array}{l}\text { Age } \\
\text { min. }\end{array}$ & $\begin{array}{l}\text { Age } \\
\text { max. }\end{array}$ & $\begin{array}{l}\text { Analytical } \\
\text { method }\end{array}$ & Related citations \\
\hline GWAS of obesity & $\begin{array}{l}\text { 10,664: initial panel } 327 \\
\text { (cases: } 164 \text { and controls: } \\
\text { 163); replication panel } \\
\text { 10,337 (cases: } 4,674 \\
\text { and controls: } 5,663 \text { ) }\end{array}$ & $\begin{array}{l}\text { Initial panel } \\
59(33 / 26) ; \\
\text { replication } \\
\text { panel } 4,126 \\
(1,678 / 2,448)\end{array}$ & $\begin{array}{l}\text { Initial panel } \\
268(131 / 137) ; \\
\text { replication } \\
\text { panel } 6,212 \\
(2,996 / 3,216)\end{array}$ & 16 & 73 & $\begin{array}{l}\text { Affymetrix } \\
406,177\end{array}$ & $\begin{array}{l}\text { Jiao et al [32] } \\
\text { Hindorff et al [18] }\end{array}$ \\
\hline $\begin{array}{l}\text { GWAS of body } \\
\text { mass index }\end{array}$ & 249,796 & 107,795 & 140,490 & 14 & 102 & $\begin{array}{l}\text { Affymetrix, } \\
\text { Illumina and } \\
\text { Perlegen about } \\
2.8 \text { million } \\
\text { (imputed) }\end{array}$ & $\begin{array}{l}\text { Speliotes et al [34] } \\
\text { Hindorff et al [18] }\end{array}$ \\
\hline $\begin{array}{l}\text { GWAS of adult } \\
\text { body mass index } \\
\text { in a British } \\
\text { population }\end{array}$ & 9,023 & 4,487 & 4,536 & 44 & 45 & $\begin{array}{l}\text { Affymetrix } \\
\text { GeneChip } \\
\text { Mapping 500K } \\
\text { Illumina } \\
\text { Infinium } \\
\text { HumanHap550 }\end{array}$ & Strachan et al [36] \\
\hline GWAS of obesity & 10,391 & $\begin{array}{l}\text { Randomly } \\
\text { selected }\end{array}$ & $\begin{array}{l}\text { Randomly } \\
\text { selected }\end{array}$ & 9 & 80 & $\begin{array}{l}\text { Illumina } \\
1,283,957 \\
\text { (imputed) }\end{array}$ & $\begin{array}{l}\text { Dorajoo et al [37] } \\
\text { Hindorff et al [18] }\end{array}$ \\
\hline
\end{tabular}

MicroRNAs are endogenous about $22 \mathrm{nt}$ RNAs that have the ability to connect to the 3'-untranslated region (3'-UTR) of target mRNAs to suppress mRNA expression at the posttranscriptional level. MicroRNAs, as a group, may directly influence expression of over $30 \%$ of mouse and human genes and more than $60 \%$ of human protein-coding genes have been under careful tension to maintain pairing to microRNAs [13]. A number of microRNAs have been associated in adipocyte development and mature adipocyte activity, including lipolysis, glucose-uptake, and insulin sensitivity [14, 15]. Interestingly, microRNAs have also been identified as essential immuno-modulators by managing the differentiation, introduction, and action of immune cells and the expression of multiple cytokines in the immune system $[11,12]$.

We conducted a novel positional omics integration study to identify microRNAs that could shed further light on the possible links between microRNAs, adipose tissue immunity/in- flammation and obesity.

\section{Methods}

We utilized the same data set we used for our prior study [16] which we generated through a search for a number of types of studies on obesity (genome-wide association, meta-analysis, transcriptomic, proteomic studies, microRNA data and epigenetic studies) in online repositories, using GWAS Central (http:// www.gwascentral.org), Medline database (www.ncbi.nlm.nih. gov/pubmed/) with search string (obesity) AND (transcriptome OR proteome OR genome-wide OR microarray OR profiling OR epigenetics). Additionally, Gene Expression Omnibus (GEO) repository (http://www.ncbi.nlm.nih.gov/geo/), ArrayExpress (http://www.ebi.ac.uk/arrayexpress/) and Stanford Microarray Database (http://smd.stanford.edu) were searched up to find 
Table 2. List of Transcriptomic Data for Initial Data Set

\begin{tabular}{|c|c|c|c|c|c|c|c|c|}
\hline $\begin{array}{l}\text { Identification } \\
\text { No. }\end{array}$ & Title & \# Individuals & \# Male & \# Female & $\begin{array}{l}\text { Age } \\
\text { Min }\end{array}$ & $\begin{array}{l}\text { Age } \\
\text { max. }\end{array}$ & Analytical method & Refernce \\
\hline GSE20950 & $\begin{array}{l}\text { Morbidly obese insulin- } \\
\text { resistant patients: omental } \\
\text { and subcutaneous } \\
\text { adipose tissue }\end{array}$ & 10 & 4 & 6 & 34 & 52 & $\begin{array}{l}\text { Affymetrix Human } \\
\text { Genome U133 Plus } 2.0 \\
\text { Array and real time PCR }\end{array}$ & Hardy et al [39] \\
\hline GSE27951 & $\begin{array}{l}\text { Adipogenesis and obesity: } \\
\text { subcutaneous adipose } \\
\text { tissue (HG-U133_Plus_2) }\end{array}$ & 14 & 10 & 4 & 45 & 49 & $\begin{array}{l}\text { Affymetrix Human } \\
\text { Genome U133 } \\
\text { Plus } 2.0 \text { Array }\end{array}$ & Keller et al [40] \\
\hline GSE15524 & $\begin{array}{l}\text { Morbid obesity: } \\
\text { subcutaneous and } \\
\text { omental adipose tissues }\end{array}$ & 11 & 2 & 9 & 37 & 47 & $\begin{array}{l}\text { CodeLink UniSet } \\
\text { Human 20K I Bioarray }\end{array}$ & $\begin{array}{l}\text { MacLaren } \\
\text { et al }[41]\end{array}$ \\
\hline GSE474 & $\begin{array}{l}\text { Obesity and fatty } \\
\text { acid oxidation }\end{array}$ & 12 & 0 & 12 & 32 & 41 & $\begin{array}{l}\text { Affymetrix Human } \\
\text { Genome U133A Array }\end{array}$ & Park et al [42] \\
\hline GSE15653 & $\begin{array}{l}\text { Obese patients with } \\
\text { and without type } 2 \\
\text { diabetes: liver }\end{array}$ & 13 & 4 & 9 & 28 & 58 & $\begin{array}{l}\text { Affymetrix Human } \\
\text { Genome U133A Array }\end{array}$ & $\begin{array}{l}\text { Pihlajamaki } \\
\text { et al [43] }\end{array}$ \\
\hline GSE22435 & $\begin{array}{l}\text { Expression of splicing } \\
\text { factor genes is reduced } \\
\text { in human obesity } \\
\text { and contributes to } \\
\text { enhanced lipogenesis }\end{array}$ & 15 & 2 & 13 & 32 & 65 & $\begin{array}{l}\text { Affymetrix Human } \\
\text { Genome U133 } \\
\text { Plus } 2.0 \text { Array }\end{array}$ & $\begin{array}{l}\text { Pihlajamaki } \\
\text { et al [44] }\end{array}$ \\
\hline GSE25401 & $\begin{array}{l}\text { Adipose tissue } \\
\text { microRNAs as regulators } \\
\text { of CCL2 production } \\
\text { in human obesity } \\
\text { (gene expression) }\end{array}$ & 30 & 0 & 30 & 41 & 45 & $\begin{array}{l}\text { Affymetrix Human } \\
\text { Gene 1.0 ST Array }\end{array}$ & Arner et al [45] \\
\hline GSE24883 & $\begin{array}{l}\text { Worsening of obesity } \\
\text { and metabolic status } \\
\text { yields similar molecular } \\
\text { adaptations subcutaneous } \\
\text { and visceral adipose tissue }\end{array}$ & 24 & 0 & 24 & 33 & 56 & $\begin{array}{l}\text { Agilent- } 014850 \text { Whole } \\
\text { Human Genome } \\
\text { Microarray 4x44K } \\
\text { G4112F (Feature } \\
\text { Number version) }\end{array}$ & $\begin{array}{l}\text { Klimcakova } \\
\text { et al }[46]\end{array}$ \\
\hline
\end{tabular}

more suitable sources of data for inclusion in our data set. We included more than 700,000 individuals (male and female) of any ethnic origin were included in the data set. Studies conducted in animals and studies missing information of gender, age and study design were excluded from the data set. The data search was started from the January 1, 2000 to January 1, 2014 [16].

\section{GWAS and meta-analysis}

Data from 20 GWA studies and two meta-analyses were ob- tained and are listed in Table 1 [17-38].

\section{Transcriptional data}

Raw data on transcriptomic alterations in adipose, omental, and subcutaneous fat, as well as in liver and in skeletal muscle were obtained from GEO repository. Transcriptomic alterations were treated as separate data sets to account for possible differences in transcriptional alterations observed in these tissue samples [39-46]. A data overview is depicted in Table 2. 


\section{Proteomic, microRNA data and epigenetics}

We have included three studies investigating proteomic, microRNA and epigenetic alterations by Arner et al [45], AbuFarha et al [47] and Barres et al [48]. The three studies were treated as separate data sets to account for their different biological layers and the different tissues samples that were utilized for the analysis.

\section{Data preparation and integration}

The positional integration approach was introduced by Maver and Peterlin [49] in 2011. To utilize the bioinformatics tool, the P-value of each signal is transformed to $-\log _{10} \mathrm{P}$ values or 1 where P-values were not available and all annotations are converted to coordinate positions. Then the tool arranges the significant signals from every type of study into the selected intervals on the DNA backbone [49]. When multiple signals from a single type of study were located in the same area, the values were summarized, to increase the score of the region. Also when no significant signal in the interval investigated was identified, it was marked with value 0 . The tool allows the user to weigh the different data sets and select the $\mathrm{kb}$ length.

For our initial analysis, the data assembly was subdivided into $50 \mathrm{~kb}$ regions, and signals from aforementioned studies were arranged on the genomic backbone into the corresponding regions according to their genomic position, but the weighing settings were not adjusted. In a second analysis, the data weighing settings were adjusted to individually double the input of genomic data, transcriptomic data, proteomic data, microRNA data and epigenetic data in comparison to all the other data sources. This was done for multiple reasons. First it is a convenient control to check if the data results are consistent, i.e. are the highest scoring gene regions also the gene regions that are identified in all weight adjusted data sets. Second, which gene regions are found in our first analysis and in more than two adjusted weight result tables. And third, in which doubled weight layers are the gene regions identified.

So all in all six high scoring gene tables (Supplementary Tables 1-6, www.jofem.org) were generated and discussed in two prior studies $[16,50]$. In this paper, our focus is directed towards the identified microRNAs and their influence on obesity-related diseases.

Evaluation was performed by searching for the identified microRNAs and obesity in the Medline database (www.ncbi. nlm.nih.gov/pubmed). The search was performed on articles that appeared in Medline using the following search string: "Obesity AND Gene", where "Gene" entry represented candidate genes located in the regions discovered by the integration process.

In addition, functional profiles of genes located in the set of top region have been profiled using Gene Ontology (GO, http://www.geneontology.org [51]) and Kyoto Encyclopedia of Genes and Genomes (KEGG, http://www.genome.jp/kegg/ [52]).

\section{Results}

In the six high scoring gene tables (Supplementary Tables 1-6, www.jofem.org), 19 microRNAs (miR-146, miR-378, miR143, miR-145, miR-194, miR-1273, miR-190, miR-561, miR151, miR-215, miR-196, miR-328, miR-208, miR-3155A, miR-933, miR-4685, miR-640, miR-4659, and miR-877) were identified.

One of the identified microRNAs is miR-378 which is highly induced during adipogenesis. In a study by Xu et al [53], matured human adipocytes were treated on day 15 with TNF- $\alpha$, IL-6, leptin, or resistin. It was demonstrated that TNF- $\alpha$, IL6 , and leptin upregulated miR-378 expression indicating that miR-378 is probably a novel mediator in the development of insulin resistance related to obesity [53]. Also miR-378 was identified to be unregulated through adipokines and cytokines and primarily through sterol-regulatory-element-binding protein (SREBP) and CCAAT/enhancer-binding protein (C/EBP) binding sites in the miR-378 promoter region [54]. Both described inflammatory processes are known to be dysregulated during obesity.

Two other microRNAs are miR-143 and miR-145 which are often studied and reported together, as the two microRNAs are located in close genomic proximity [55]. In 2004, miR143 was initially described as a positive manager of human adipocyte differentiation via results of ERK5 signaling [56]. It has been shown that miR-143 is the only microRNA to date to be similarly controlled during human and mouse adipocyte differentiation [57]. MiR-143 expression was elevated in the mesenteric adipose of high-fat diet-fed mice [58], and TNF- $\alpha$ treatment declined the expression of miR-143 suggesting that obesity-associated inflammation may dysregulate miR-143 expression affecting adipogenesis [59]. Another study demonstrated that TNF- $\alpha$ and IL- 6 had only a neglectable effect on miR-143 expression, whereas free fatty acids, resistin, and leptin decrease miR-143 expression in human adipocytes. These results suggest that the expression of miR-143 is influenced by a variety of factors that are related to insulin sensitivity. Therefore, miR-143 may be an essential mediator in the development of obesity-related insulin resistance [60].

In combination, miR-143-145 cluster knockout mice were protected from obesity-induced insulin resistance, while conditional overexpression of miR-143 leads to a diminished insulin resistance in diet-induced obesity.

The function for miR-145 in obesity is less apparent, though a commonly believed function has emerged in lipolysis. Obesity elevates the expression of the miR-143-145 cluster in adipose tissue and liver of humans and mice [61-64], and overexpression of miR-145 heightened TNF- $\alpha$ secretion and lipolysis in human adipocytes in vitro via an NF- $\kappa \mathrm{B}$ mechanism [62]. A contradictory study, however, demonstrated that miR-145 overexpression diminishes lipolysis [63]. Although the implication of miR-145 in insulin resistance is still under investigation, the genomic association with miR-143 suggests a high potential of involvement in obesity and obesity-related diseases.

Another microRNA that plays a role in the inflammatory signaling pathway, where palmitic acid activates the Toll-like 
receptor 4 (TLR4) is miR-194. This increases a key molecule tumor necrosis factor receptor-associated factor 6 (TRAF6) and cytokines TNF- $\alpha$ and tumor growth factor-beta. Furthermore, it decreases miR-194 expression in THP-1 monocytic cells. Overexpression of TNF- $\alpha$ and tumor growth factor-beta leads to cell injury, accumulation of immune cells, inducing more proinflammatory cytokines and production of fibrosisrelated proteins, which encourage the development of obesityrelated diseases. It was also identified that TRAF6 was a target gene for miR-194, which weakens palmitic acid-induced TRAF6 upregulation and cytokine TNF- $\alpha$ expression. These outcomes propose that after palmitic acid introduction, downregulated miR-194 results in TRAF6 (a key molecule in the TLR4 pathway) overexpression and additionally regulates downstream cytokine expression [65].

And finally we identified miR-146b which is a microRNA that can manage the inflammatory process by constricting cytokine signaling via the NF- $\mathrm{kB}$ pathway. Mature human adipocytes, which respond to proinflammatory cytokines by a highly upregulated expression of miR-146b, indicated a novel role for miR-146b in adipose tissue inflammation [66].

MiR-208 is significantly dysregulated in heart tissue with myocardial infarcts compared to healthy adult hearts [67]. MiR-1273, miR-190, miR-561, miR-151, miR-215, miR-196, and miR-328 are suggested to play a role in different types of cancer [68-75], whereas miR-3155A, miR-933, miR-4685, miR-640, and miR-4659 have not been associated to a specific function or disease yet. It has been stated that obesity is strongly associated with alterations in the physiological function of adipose tissue, resulting in insulin resistance, chronic inflammation, and changed secretion of adipokines. Several of these factors, such as insulin resistance, elevated levels of leptin, endogenous sex steroids and plasminogen activator inhibitor-1, decreased levels of adiponectin, and chronic inflammation, and are involved in carcinogenesis and cancer progression [76]. Therefore, the identified cancer associated microRNAs could be of interest for further research to establish a possible implication or involvement in obesity.

Also miR-208 should be further investigated as overweight and obesity are risk factors for myocardial infarct [77] and a connection could be plausible.

Last but not least, results have indicated that miR-877 could influence the sensitivity of paclitaxel treatment in hepatocellular carcinoma cell lines by targeting FOXM1 [78].

\section{Discussion}

Of the 19 identified microRNAs, five (miR-146, miR-378, miR-143, miR-145, and miR-194) could be directly linked to adipose tissue inflammation and obesity-related diseases, such as insulin resistance. One of them, miR-194, is even able to activate TLR4 which is known to trigger inflammation in murine adipocytes, lipopolysaccharide and encourage the secretion of proinflammatory cytokines via downstream initiation of nuclear factor kappa B or mitogen-activated protein kinases signaling pathways [79].

In our prior study, we discussed two challenges of the po- sition-centric integration approach and how we tackled them in the course of our study. The first challenge arose due to contradictions in gene annotation used for publishing the results in various types of large-scale studies. This is a common problem for data integration. Annotations for reporting significant results of these studies are often not consistent. Transformation of these annotations to a common gene identifier is often associated with obstacles $[16,49]$.

The second challenge is that gene regions located outside the gene's coding region which may account for disease susceptibility may be overlooked [16, 49]. Various genetic changes are located close to gene regulatory regions several kilo bases upstream or downstream and influence gene expression and/or function [80].

To address the prior mentioned challenges of inadequate conversion of annotations by converting gene identifiers to their positions on genome coordinates. Where no conversion could be identified, BLAST services were utilized to detect the corresponding genomic positions. This approach also takes into consideration interplays between adjacent genetic alterations and is not limited by the nature of genetic modifications to be included in the integration process. It is flexible enough to permit inclusion of anticipated data from studies investigating epigenetic modifications and microRNA changes in human disease.

One of two other limitations that should also be kept in mind is the choice of region size used for integration, which is not straightforward. Choosing a region too small may result in missing important long-range interactions, while choosing a larger region may result in high amount of false positive genes [16].

Another issue is of course the limitation of the selected studies and their study designs, which limits the outcome of our study. To mention one example, we could bring up age and gender differences, which could not be investigated in this article even though it might be fruitful to examine genetic effects separately by sex and age groups. The utilized studies often adjusted for age and sex, but especially in case of the utilized GWAS and meta-analysis, the significantly identified gene regions cannot be traced back to an individual or a group of participants.

\section{Conclusion}

To further understand the role of microRNAs in whole-body metabolism and the pathophysiology of obesity we have utilized a new positional integration method that includes microRNA profiling data from human disease in addition to genomic-, transcriptomic-, proteomic- and epigenetic data, which has yielded a number of reasonable microRNAs that are involved in inflammatory processes that occur during obesity (miR-146, miR-378, miR-143, miR-145, and miR-194). Interestingly, almost all of the identified microRNAs are shown to be modulated during inflammatory processes in cancer, cardiovascular problems or type 2 diabetes.

Future studies could be directed towards the clarification of the role of microRNAs in 1) the circulation and consequences in distal tissues, 2) inherited and adaptive immune 
cell-mediated inflammation during overnutrition, 3) beta cell expansion in overnutrition and deficiency in T2DM, 4) central control of appetite and food intake and 5) cross-generational result of obesity.

\section{Acknowledgments}

We thank the Austrian Science Fund FWF (project no. AP2658721) for funding.

\section{Conflicts of Interest}

\section{References}

1. Boutin P, Froguel P. Genetics of Human Obesity. Best Pract Res Clin Endocrinol Metab. 2001;15(3):391-404.

2. Clinical Guidelines on the Identification, Evaluation, and Treatment of Overweight and Obesity in Adults--the Evidence Report. National Institutes of Health. Obes Res. 1998;6(Suppl 2):51S-209S.

3. World Health Organization, Obesity, 2008.

4. Kopelman P. Health Risks Associated with Overweight and Obesity. Obes Rev. 2007;8(Suppl 1):13-17.

5. Maury E, Brichard SM. Adipokine Dysregulation, Adipose Tissue Inflammation and Metabolic Syndrome. Mol Cell Endocrinol. 2010;314(1):1-16.

6. Trujillo ME, Scherer PE. Adipose Tissue-Derived Factors: Impact on Health and Disease. Endocr Rev. 2006;27(7):762-778.

7. Maury E, Ehala-Aleksejev K, Guiot Y, Detry R, Vandenhooft A, Brichard SM. Adipokines Oversecreted by Omental Adipose Tissue in Human Obesity. Am J Physiol Endocrinol Metab. 2007;293(3):E656-665.

8. Bourlier V, Zakaroff-Girard A, Miranville A, De Barros S, Maumus M, Sengenes C, Galitzky J, et al. Remodeling Phenotype of Human Subcutaneous Adipose Tissue Macrophages. Circulation. 2008;117(6):806-815.

9. Faust IM, Johnson PR, Stern JS, Hirsch J. Diet-Induced Adipocyte Number Increase in Adult Rats: A New Model of Obesity. Am J Physiol. 1978;235(3):E279-286.

10. Henegar C, Tordjman J, Achard V, Lacasa D, Cremer I, Guerre-Millo M, Poitou C, et al. Adipose Tissue Transcriptomic Signature Highlights the Pathological Relevance of Extracellular Matrix in Human Obesity. Genome Biol. 2008;9(1):R14.

11. Lu LF, Liston A. Microrna in the Immune System, Microrna as an Immune System. Immunology. 2009;127(3):291298.

12. Sayed D, Abdellatif M. Micrornas in Development and Disease. Physiol Rev. 2011;91(3):827-887.

13. Lewis BP, Burge CB, Bartel DP. Conserved Seed Pairing, Often Flanked by Adenosines, Indicates That Thousands of Human Genes Are Microrna Targets. Cell. 2005;120(1):15-20.

14. Heneghan HM, Miller N, Kerin MJ. Role of Micrornas in Obesity and the Metabolic Syndrome. Obes Rev.
2010;11(5):354-361.

15. Alexander R, Lodish H, Sun L. Micrornas in Adipogenesis and as Therapeutic Targets for Obesity. Expert Opin Ther Targets. 2011;15(5):623-636.

16. Gibson G. Wellness and Health Omics Linked to the Environment: The Whole Approach to Personalized Medicine. Adv Exp Med Biol. 2014;799:1-14.

17. Timpson NJ, Lindgren CM, Weedon MN, Randall J, Ouwehand WH, Strachan DP, Rayner NW, et al. AdiposityRelated Heterogeneity in Patterns of Type 2 Diabetes Susceptibility Observed in Genome-Wide Association Data. Diabetes. 2009;58(2):505-510.

18. Hindorff LA, Sethupathy P, Junkins HA, Ramos EM, Mehta JP, Collins FS, Manolio TA. Potential Etiologic and Functional Implications of Genome-Wide Association Loci for Human Diseases and Traits. Proc Natl Acad Sci U S A. 2009;106(23):9362-9367.

19. Steinthorsdottir V, Thorleifsson G, Reynisdottir I, Benediktsson R, Jonsdottir T, Walters GB, Styrkarsdottir U, et al. A Variant in Cdkal1 Influences Insulin Response and Risk of Type 2 Diabetes. Nat Genet. 2007;39(6):770-775.

20. Johnson AD, O'Donnell CJ. An Open Access Database of Genome-Wide Association Results. BMC Med Genet. 2009; 10:6.

21. Heard-Costa NL, Zillikens MC, Monda KL, Johansson A, Harris TB, Fu M, Haritunians T, et al. Nrxn3 Is a Novel Locus for Waist Circumference: A Genome-Wide Association Study from the Charge Consortium. PLoS Genet. 2009;5(6):e1000539.

22. Cotsapas C, Speliotes EK, Hatoum IJ, Greenawalt DM, Dobrin R, Lum PY, Suver C, et al. Common Body Mass Index-Associated Variants Confer Risk of Extreme Obesity. Hum Mol Genet. 2009;18(18):3502-3507.

23. Frayling TM, Timpson NJ, Weedon MN, Zeggini E, Freathy RM, Lindgren CM, Perry JR, et al. A Common Variant in the Fto Gene Is Associated with Body Mass Index and Predisposes to Childhood and Adult Obesity. Science. 2007;316(5826):889-894.

24. Loos RJ, Lindgren CM, Li S, Wheeler E, Zhao JH, Prokopenko I, Inouye $\mathrm{M}$, et al. Common Variants near Mc4r Are Associated with Fat Mass, Weight and Risk of Obesity. Nat Genet. 2008;40(6):768-775.

25. Willer CJ, Speliotes EK, Loos RJ, Li S, Lindgren CM, Heid IM, Berndt SI, et al. Six New Loci Associated with Body Mass Index Highlight a Neuronal Influence on Body Weight Regulation. Nat Genet. 2009;41(1):25-34.

26. Thorleifsson G, Walters GB, Gudbjartsson DF, Steinthorsdottir V, Sulem P, Helgadottir A, Styrkarsdottir U, et al. Genome-Wide Association Yields New Sequence Variants at Seven Loci That Associate with Measures of Obesity. Nat Genet. 2009;41(1):18-24.

27. Fox CS, Heard-Costa N, Cupples LA, Dupuis J, Vasan RS, Atwood LD. Genome-Wide Association to Body Mass Index and Waist Circumference: The Framingham Heart Study 100k Project. BMC Med Genet. 2007;8(Suppl 1):S18.

28. Scuteri A, Sanna S, Chen WM, Uda M, Albai G, Strait J, Najjar S, et al. Genome-Wide Association Scan Shows Genetic Variants in the Fto Gene Are Associated with 
Obesity-Related Traits. PLoS Genet. 2007;3(7):e115.

29. Johansson A, Marroni F, Hayward C, Franklin CS, Kirichenko AV, Jonasson I, Hicks AA, et al. Linkage and Genome-Wide Association Analysis of Obesity-Related Phenotypes: Association of Weight with the Mgat1 Gene. Obesity (Silver Spring). 2010;18(4):803-808.

30. Paternoster L, Evans DM, Nohr EA, Holst C, Gaborieau V, Brennan P, Gjesing AP, et al. Genome-Wide PopulationBased Association Study of Extremely Overweight Young Adults--the Goya Study. PLoS One. 2011;6(9):e24303.

31. Wang K, Li WD, Zhang CK, Wang Z, Glessner JT, Grant SF, Zhao H, et al. A Genome-Wide Association Study on Obesity and Obesity-Related Traits. PLoS One. 2011;6(4):e18939.

32. Jiao H, Arner P, Hoffstedt J, Brodin D, Dubern B, Czernichow S, van't Hooft F, et al. Genome Wide Association Study Identifies Kcnma1 Contributing to Human Obesity. BMC Med Genomics. 2011;4:51.

33. Ng MC, Hester JM, Wing MR, Li J, Xu J, Hicks PJ, Roh $\mathrm{BH}$, et al. Genome-Wide Association of Bmi in African Americans. Obesity (Silver Spring). 2012;20(3):622-627.

34. Speliotes EK, Willer CJ, Berndt SI, Monda KL, Thorleifsson G, Jackson AU, Lango Allen H, et al. Association Analyses of 249,796 Individuals Reveal 18 New Loci Associated with Body Mass Index. Nat Genet. 2010;42(11):937-948.

35. Scherag A, Dina C, Hinney A, Vatin V, Scherag S, Vogel CI, Muller TD, et al. Two New Loci for Body-Weight Regulation Identified in a Joint Analysis of GenomeWide Association Studies for Early-Onset Extreme Obesity in French and German Study Groups. PLoS Genet. 2010;6(4):e1000916.

36. Strachan DP, Rudnicka AR, Power C, Shepherd P, Fuller E, Davis A, Gibb I, et al. Lifecourse Influences on Health among British Adults: Effects of Region of Residence in Childhood and Adulthood. Int $\mathrm{J}$ Epidemiol. 2007;36(3):522-531.

37. Dorajoo R, Blakemore AI, Sim X, Ong RT, Ng DP, Seielstad M, Wong TY, et al. Replication of 13 Obesity Loci among Singaporean Chinese, Malay and Asian-Indian Populations. Int J Obes (Lond). 2012;36(1):159-163.

38. Lindgren CM, Heid IM, Randall JC, Lamina C, Steinthorsdottir V, Qi L, Speliotes EK, et al. GenomeWide Association Scan Meta-Analysis Identifies Three Loci Influencing Adiposity and Fat Distribution. PLoS Genet. 2009;5(6):e1000508.

39. Hardy OT, Perugini RA, Nicoloro SM, Gallagher-Dorval K, Puri V, Straubhaar J, Czech MP. Body Mass Index-Independent Inflammation in Omental Adipose Tissue Associated with Insulin Resistance in Morbid Obesity. Surg Obes Relat Dis. 2011;7(1):60-67.

40. Keller P, Gburcik V, Petrovic N, Gallagher IJ, Nedergaard J, Cannon B, Timmons JA. Gene-Chip Studies of Adipogenesis-Regulated Micrornas in Mouse Primary Adipocytes and Human Obesity. BMC Endocr Disord. 2011;11:7.

41. MacLaren RE, Cui W, Lu H, Simard S, Cianflone K. Association of Adipocyte Genes with Asp Expression: A Microarray Analysis of Subcutaneous and Omental Adipose
Tissue in Morbidly Obese Subjects. BMC Med Genomics. 2010;3:3.

42. Park JJ, Berggren JR, Hulver MW, Houmard JA, Hoffman EP. Grb14, Gpd1, and Gdf8 as Potential Network Collaborators in Weight Loss-Induced Improvements in Insulin Action in Human Skeletal Muscle. Physiol Genomics. 2006;27(2):114-121.

43. Pihlajamaki J, Boes T, Kim EY, Dearie F, Kim BW, Schroeder J, Mun E, et al. Thyroid Hormone-Related Regulation of Gene Expression in Human Fatty Liver. J Clin Endocrinol Metab. 2009;94(9):3521-3529.

44. Pihlajamaki J, Lerin C, Itkonen P, Boes T, Floss T, Schroeder J, Dearie F, et al. Expression of the Splicing Factor Gene Sfrs10 Is Reduced in Human Obesity and Contributes to Enhanced Lipogenesis. Cell Metab. 2011;14(2):208-218.

45. Arner E, Mejhert N, Kulyte A, Balwierz PJ, Pachkov M, Cormont M, Lorente-Cebrian S, et al. Adipose Tissue Micrornas as Regulators of $\mathrm{Ccl} 2$ Production in Human Obesity. Diabetes. 2012;61(8):1986-1993.

46. Klimcakova E, Roussel B, Marquez-Quinones A, Kovacova Z, Kovacikova M, Combes M, Siklova-Vitkova M, et al. Worsening of Obesity and Metabolic Status Yields Similar Molecular Adaptations in Human Subcutaneous and Visceral Adipose Tissue: Decreased Metabolism and Increased Immune Response. J Clin Endocrinol Metab. 2011;96(1):E73-82.

47. Abu-Farha M, Tiss A, Abubaker J, Khadir A, Al-Ghimlas F, Al-Khairi I, Baturcam E, et al. Proteomics Analysis of Human Obesity Reveals the Epigenetic Factor Hdac4 as a Potential Target for Obesity. PLoS One. 2013;8(9):e75342.

48. Barres R, Kirchner H, Rasmussen M, Yan J, Kantor FR, Krook A, Naslund E, et al. Weight Loss after Gastric Bypass Surgery in Human Obesity Remodels Promoter Methylation. Cell Rep. 2013;3(4):1020-1027.

49. Maver A, Peterlin B. Positional Integratomic Approach in Identification of Genomic Candidate Regions for Parkinson's Disease. Bioinformatics. 2011;27(14):1971-1978.

50. Brettfeld C, Maver A, Aumuller E, Peterlin B, Haslberger AG. Integration and Weighing of Omics Data for Obesity. J Diabetes Metab. 2016;7:690.

51. Ashburner M, Ball CA, Blake JA, Botstein D, Butler H, Cherry JM, Davis AP, et al. Gene Ontology: Tool for the Unification of Biology. The Gene Ontology Consortium. Nat Genet. 2000;25(1):25-29.

52. Ogata H, Goto S, Sato K, Fujibuchi W, Bono H, Kanehisa M. Kegg: Kyoto Encyclopedia of Genes and Genomes. Nucleic Acids Res. 1999;27(1):29-34.

53. Xu LL, Shi CM, Xu GF, Chen L, Zhu LL, Zhu L, Guo XR, et al. Tnf-Alpha, Il-6, and Leptin Increase the Expression of Mir-378, an Adipogenesis-Related Microrna in Human Adipocytes. Cell Biochem Biophys. 2014;70(2):771-776.

54. Jiang X, Xue M, Fu Z, Ji C, Guo X, Zhu L, Xu L, et al. Insight into the Effects of Adipose Tissue Inflammation Factors on Mir-378 Expression and the Underlying Mechanism. Cell Physiol Biochem. 2014;33(6):17781788 .

55. Cordes KR, Sheehy NT, White MP, Berry EC, Morton 
SU, Muth AN, Lee TH, et al. Mir-145 and Mir-143 Regulate Smooth Muscle Cell Fate and Plasticity. Nature. 2009;460(7256):705-710.

56. Esau C, Kang X, Peralta E, Hanson E, Marcusson EG, Ravichandran LV, Sun Y, et al. Microrna-143 Regulates Adipocyte Differentiation. J Biol Chem. 2004;279(50):52361-52365.

57. Kajimoto K, Naraba H, Iwai N. Microrna and 3t3-L1 PreAdipocyte Differentiation. RNA. 2006;12(9):1626-1632.

58. Takanabe R, Ono K, Abe Y, Takaya T, Horie T, Wada H, Kita T, et al. Up-Regulated Expression of Microrna-143 in Association with Obesity in Adipose Tissue of Mice Fed High-Fat Diet. Biochem Biophys Res Commun. 2008;376(4):728-732.

59. Xie H, Lim B, Lodish HF. Micrornas Induced During Adipogenesis That Accelerate Fat Cell Development Are Downregulated in Obesity. Diabetes. 2009;58(5):10501057.

60. Zhu L, Shi C, Ji C, Xu G, Chen L, Yang L, Fu Z, et al. Ffas and Adipokine-Mediated Regulation of HsaMir-143 Expression in Human Adipocytes. Mol Biol Rep. 2013;40(10):5669-5675.

61. Heneghan HM, Miller N, McAnena OJ, O'Brien T, Kerin MJ. Differential Mirna Expression in Omental Adipose Tissue and in the Circulation of Obese Patients Identifies Novel Metabolic Biomarkers. J Clin Endocrinol Metab. 2011;96(5):E846-850.

62. Lorente-Cebrian S, Mejhert N, Kulyte A, Laurencikiene J, Astrom G, Heden P, Ryden M, et al. Micrornas Regulate Human Adipocyte Lipolysis: Effects of Mir-145 Are Linked to Tnf-Alpha. PLoS One. 2014;9(1):e86800.

63. Lin YY, Chou CF, Giovarelli M, Briata P, Gherzi R, Chen CY. Ksrp and Microrna 145 Are Negative Regulators of Lipolysis in White Adipose Tissue. Mol Cell Biol. 2014;34(12):2339-2349.

64. Wen F, Yang Y, Jin D, Sun J, Yu X, Yang Z. Mirna-145 Is Involved in the Development of Resistin-Induced Insulin Resistance in Hepg2 Cells. Biochem Biophys Res Commun. 2014;445(2):517-523.

65. Tian H, Liu C, Zou X, Wu W, Zhang C, Yuan D. Mirna-194 Regulates Palmitic Acid-Induced Toll-Like Receptor 4 Inflammatory Responses in Thp-1 Cells. Nutrients. 2015;7(5):3483-3496.

66. Shi C, Zhu L, Chen X, Gu N, Chen L, Yang L, Pang L, et al. Il-6 and Tnf-Alpha Induced Obesity-Related Inflammatory Response through Transcriptional Regulation of Mir-146b. J Interferon Cytokine Res. 2014;34(5):342348.

67. Bostjancic E, Zidar N, Stajer D, Glavac D. Micrornas Mir-1, Mir-133a, Mir-133b and Mir-208 Are Dysregulated in Human Myocardial Infarction. Cardiology. 2010;115(3):163-169.

68. Reshmi G, Chandra SS, Babu VJ, Babu PS, Santhi WS,
Ramachandran S, Lakshmi S, et al. Identification and Analysis of Novel Micrornas from Fragile Sites of Human Cervical Cancer: Computational and Experimental Approach. Genomics. 2011;97(6):333-340.

69. Cizeron-Clairac G, Lallemand F, Vacher S, Lidereau R, Bieche I, Callens C. Mir-190b, the Highest up-Regulated Mirna in Eralpha-Positive Compared to Eralpha-Negative Breast Tumors, a New Biomarker in Breast Cancers? BMC Cancer. 2015;15:499.

70. Ding J, Huang S, Wu S, Zhao Y, Liang L, Yan M, Ge C, et al. Gain of Mir-151 on Chromosome 8q24.3 Facilitates Tumour Cell Migration and Spreading through Downregulating Rhogdia. Nat Cell Biol. 2010;12(4):390-399.

71. Guan X, Liu H, Ju J, Li Y, Li P, Wang LE, Brewster AM, et al. Genetic Variant Rs16430 6bp > 0bp at the MicrornaBinding Site in Tyms and Risk of Sporadic Breast Cancer Risk in Non-Hispanic White Women Aged $</=55$ Years. Mol Carcinog. 2015;54(4):281-290.

72. Li JR, Wang JQ, Gong Q, Fang RH, Guo YL. Microrna-328 Inhibits Proliferation of Human Melanoma Cells by Targeting Tgfbeta2. Asian Pac J Cancer Prev. 2015;16(4):1575-1579.

73. Liu M, Du Y, Gao J, Liu J, Kong X, Gong Y, Li Z, et al. Aberrant Expression Mir-196a Is Associated with Abnormal Apoptosis, Invasion, and Proliferation of Pancreatic Cancer Cells. Pancreas. 2013;42(7):1169-1181.

74. Faltejskova P, Svoboda M, Srutova K, Mlcochova J, Besse A, Nekvindova J, Radova L, et al. Identification and Functional Screening of Micrornas Highly Deregulated in Colorectal Cancer. J Cell Mol Med. 2012;16(11):26552666.

75. Ishimoto T, Sugihara H, Watanabe M, Sawayama H, Iwatsuki M, Baba Y, Okabe H, et al. Macrophage-Derived Reactive Oxygen Species Suppress Mir-328 Targeting Cd44 in Cancer Cells and Promote Redox Adaptation. Carcinogenesis. 2014;35(5):1003-1011.

76. van Kruijsdijk RC, van der Wall E, Visseren FL. Obesity and Cancer: The Role of Dysfunctional Adipose Tissue. Cancer Epidemiol Biomarkers Prev. 2009;18(10):25692578.

77. Thomsen M, Nordestgaard BG. Myocardial Infarction and Ischemic Heart Disease in Overweight and Obesity with and without Metabolic Syndrome. JAMA Intern Med. 2014;174(1):15-22.

78. Huang X, Qin J, Lu S. Up-Regulation of Mir-877 Induced by Paclitaxel Inhibits Hepatocellular Carcinoma Cell Proliferation Though Targeting Foxm1. Int J Clin Exp Pathol. 2015;8(2):1515-1524.

79. Schaffler A, Scholmerich J. Innate Immunity and Adipose Tissue Biology. Trends Immunol. 2010;31(6):228-235.

80. Kleinjan DA, van Heyningen V. Long-Range Control of Gene Expression: Emerging Mechanisms and Disruption in Disease. Am J Hum Genet. 2005;76(1):8-32. 